\title{
The Development of Halal Tourism Industry for the Muslim Community in Langkawi, Kedah
}

\section{Nur 'Atiqah Adnan and Azreen Hamiza Abdul}

To Link this Article: http://dx.doi.org/10.6007/IJARBSS/v11-i11/11546

DOI:10.6007/IJARBSS/v11-i11/11546

Received: 12 September 2021, Revised: 16 October 2021, Accepted: 30 October 2021

Published Online: 06 November 2021

In-Text Citation: (Adnan \& Abdul, 2021)

To Cite this Article: Adnan, N. 'Atiqah, \& Abdul, A. H. (2021). The Development of Halal Tourism Industry for the Muslim Community in Langkawi, Kedah. International Journal of Academic Research in Business and Social Sciences, 11(11), 467-474.

\section{Copyright: @ 2021 The Author(s)}

Published by Human Resource Management Academic Research Society (www.hrmars.com)

This article is published under the Creative Commons Attribution (CC BY 4.0) license. Anyone may reproduce, distribute, translate and create derivative works of this article (for both commercial and non-commercial purposes), subject to full attribution to the original publication and authors. The full terms of this license may be seen at: http://creativecommons.org/licences/by/4.0/legalcode

\section{Vol. 11, No. 11, 2021, Pg. $467-474$}

Full Terms \& Conditions of access and use can be found at http://hrmars.com/index.php/pages/detail/publication-ethics 


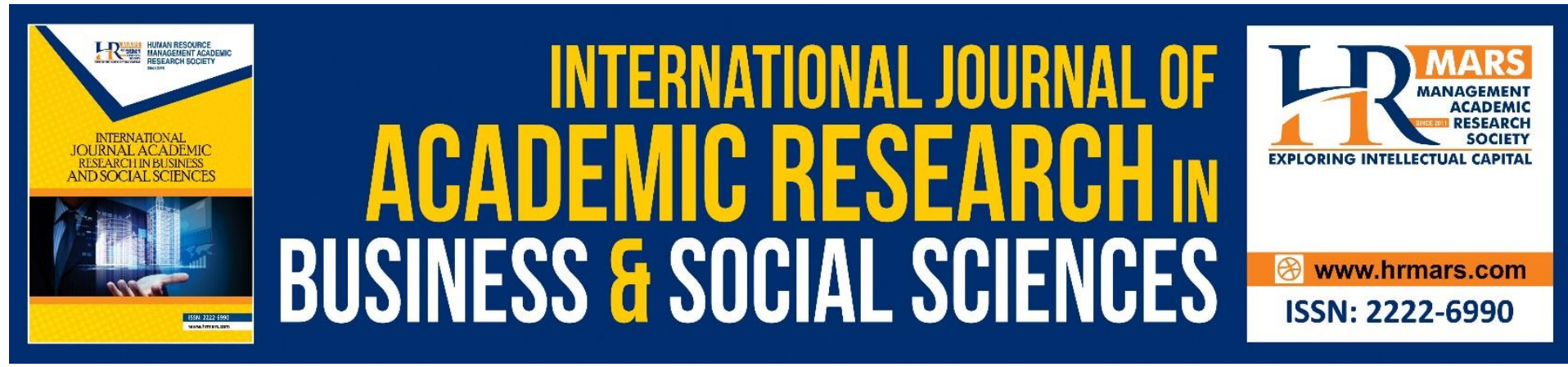

\title{
The Development of Halal Tourism Industry for the Muslim Community in Langkawi, Kedah
}

\author{
Nur 'Atiqah Adnan and Azreen Hamiza Abdul \\ Centre for Islamic Development Management Sudies (ISDEV), Universiti Sains Malaysia, \\ 11800 USM, Penang, Malaysia.
}

\begin{abstract}
The development of the tourism industry in Malaysia has been thriving over time. In fact, tourism is one of the important elements in the growth from the social, economic and environmental dimensions. Malaysia is known as halal tourism destination or also known as Muslim Friendly tourism. Looking at the tourism development in Langkawi, the growth of the tourism industry has been positive with the increasing tourist arrivals every year before the pandemic strike. This paper discusses on the concept of halal tourism, tourism development and tourism activities in Langkawi. This study uses the basic qualitative methods from data collected via documents from secondary data sources. The collected data are analyzed using content analysis. The findings show that Langkawi is a potential area for the development of Islamic halal development especially in halal tourism. The findings of this study are expected to contribute to the extension of studies and strategies to curb the issues that endure to realization of the development of halal tourism in Langkawi.
\end{abstract}

Keywords: Halal Tourism, Muslim Friendly Tourism, Langkawi, Muslim Community

\section{Introduction}

Tourism is a major contributor towards the development process that leads to the economic growth of a country. The development of tourism affects the economic development and life of the local community in general. Tourism generally leads to a form of activity that spans a variety of sectors such as economic, social, cultural and environmental. In this regard, tourists are seen as activities that describe sectors that impact multiple dimensions (Lickorish \& Jenkins, 1997).

Camilleri (2017) define tourism as an activity of movement or short-term travel of an individual to an area that is outside their residence that usually for employment purposes. Tourism is an individual movement activity that includes specific purposes for a visit to an area. Tourist usually travel to gain new experience and be part of the local community. Before the pandemic starts, over the past few years, tourism activity has shown substantial and sustained growth in terms of both the number of tourists and tourism receipts for Malaysia. According to Rasit et al (2014), tourism can develop and help the formation of a multiracial local community in Malaysia. Tourism development in Malaysia is in a strong position and provides the third largest return in Malaysia. Malaysia has shown a consistency in the tourism 
industry growth rate. Government of Malaysia has made significant efforts to ensure that tourism and hospitality plays a vital role to the economy. Tourism Malaysia has been extensively promoting the campaign 'Visit Malaysia' in 2014. Due to the intense promotions by the government, Malaysia has successfully attracted and build assurance to Muslim travellers to visit Malaysia (Aziz, 2018).

Malaysia is declared as one of the countries that have best developed ecosystem for Halal travel (Reuters, 2016). Malaysia is the most culturally significant country with different races and ethnics living under one roof with its own unique culture. According to Ramli et al (2015), Malaysia is a country that is rich in heritage and cultural customs that can be highlighted as one of the attractions for tourists to visit Malaysia. In this regard, it clearly shows that Malaysia is a country that has its own charm in attracting tourists to visit every year.

This escalation growth pattern in the tourism industry has established Malaysia to become the major player in Muslim Friendly Tourism (MFT) or also known as halal tourism to offer the best products and services for both Muslim and non-Muslim travellers (Aziz, 2018). More achievement can be seen as stated in the Global Muslim Travel Index (GTMI) 2020, Malaysia continues to top the index for the eighth consecutive year. Malaysia has managed to maintain its leadership as one of the best destinations for Muslim travellers in terms of the various criteria that were analysed in GTMI 2020. Muslim friendly Malaysia or halal tourism in Malaysia offers a widespread assortment of products and services for both Muslims and nonMuslims to experience including the facilities, halal food and beverages as well as Muslim friendly accommodation (Aziz, 2018). Ibrahim et al (2019), said that halal tourism covers a wide range of aspects based on Islamic laws that must be complied with. Through the concept of halal, there are various purposes of tourism can be done such as worship, brotherhood, entrepreneurship, dissemination of knowledge and preaching, as well as appreciating the beauty of Allah SWT creation.

According to Rahman (2018), halal tourism is a new industry that is rapidly having an increase in demand. Malaysia is a country with a majority Muslim community. Referring to the population estimated in 2020, 69.6 per cent are Bumiputera, 22.6 per cent are Chinese, 6.8 per cent are Indians and 1.0 per cent are other ethnicities (Department of Statistics Malaysia, 2021). It can be found that Malaysia has numerous and reachable halal products and services that perfectly accommodate all travellers to discover and experience the uniqueness of Malaysia. One of the attractive islands that is always has become the target place for traveller is Langkawi. Langkawi is an island surrounded by 99 small islands that makes Langkawi a unique island. Most environmental researchers choose Langkawi because Langkawi is rich in biodiversity and attractive landforms. Previously, the local community in Langkawi was heavily involved in agriculture and fishing activities. The development of the tourism sector has had a significant impact on the employment of local communities (Salleh et al., 2014). This indicates a significant change in the field of work of the local community. The tourism sector leads to significant changes in terms of physical tourism areas, economic development and changes to local communities (Ismail, 2015).

\section{Research Method}

This study adopts a qualitative method with basic research design. Secondary data is collected from the secondary sources such as literature, reports and documents that are related to halal 
tourism. Based on the eccentric figure and report findings, the development of Halal tourism for the Muslim community in Langkawi is very significant to uncover in order to maximize the economics benefits and to maintain the sustainability of the tourism industry of the attractive island. The first section of this paper covers the intended grasp of the general overview of halal tourism in Malaysia. Then the discussion continues to reveal the development of halal tourism in Langkawi.

\section{Results and Discussion}

a) Halal Tourism Concept

Halal tourism is seen as a form of activity that helps the Muslim community to visit and enjoy holidays with things that do not violate religious law. According to Kamarudin and Ismail (2012), halal tourism can be linked to the concept of worship activities by highlighting the economic, cultural and religious sectors of the Muslim community, especially in a country with Muslim majority population. Worship activities that can be seen in tourism such as performing Hajj, Umrah and Pilgrimage. This explains that the original concept of halal tourism is characterized by towards the devotion to Islam.

Tourism that is friendly to the Muslim community is generally also known as 'Muslim Friendly Tourism', 'Islamic Tourism' and 'Halal Tourism'. Halal tourism is a form of tourism product that does not separate the demands of religion in carrying out recreational activities and visits to an area visited (Kamaruddin, 2018). Looking at non-Muslim countries, the concept of halal tourism has been promoted vigorously such as in Japan, Korea and Taiwan. These countries have provided prayer rooms at airports, Muslim friendly accommodation as well as halal food to attract Muslims around the world to visit. By doing this, it shows that the untapped market of the halal tourism has a big potential that can integrate the tourism planning destination for travellers (Cetin \& Dincer, 2018).

Any strategy undertaken by countries wishing to develop halal tourism products should be guided by Shariah law. The development of halal tourism is growing every year due to the demand and growth of the Muslim population around the world (Battour \& Ismail, 2015). Halal tourism encompasses the halal service system. Various shariah-compliant elements are required in making tourism one of the halal industrial hubs. All services need to adhere to Islamic values such as market operations, market practices, individual relations, cultural and normative fundamentals, value chain through suppliers, and all basic things that involved in a business (Kodirov et al., 2020).

\section{b) Tourism Development in Langkawi}

Langkawi is a district under the state of Kedah located in the Northern Peninsula of Malaysia. Langkawi is an island full of natural attractions, cultural attractions and historical heritage that has its own charm. According to Mokhtar (2010), Langkawi is a germ for the state of Kedah which was strengthened by the recognition of Langkawi Geopark as one of the world heritage site from UNESCO in 2007. In this regard, the Kedah state government has sought to ensure that the tourism development sector in Langkawi continues by offering various types of additional attractions to tourists to visit Langkawi especially in promoting halal tourism and eco-tourism. 
The influx of tourists is increasing every year in Langkawi. There are various initiatives created by the Kedah state government together with the Langkawi City Council to ensure that various programmes and infrastructure development for tourism facilities is further strengthened (Kedah State Socio-Economic Report, 2019). Various plans are developed to safeguard the tourism sector in Langkawi for intanse on th project of the Pantai Chenang Special Area Plan (RKK Pantai Chenang). Under the Pantai Chenang RKK, the local government and the Langkawi Development Authority (LADA) have focused on the development of infrastructure and public facilities around the Pantai Chenang area. This is because, the Chenang Beach area is a main attraction and recreation centre that is often visited by domestic and international travellers.

Apart from that, Langkawi is a major tourism attraction because Langkawi is a tourism district recognized by the Kedah state government (Kedah State Socio-Economic Report, 2019). Referring to the number of tourist arrivals in Langkawi, it shows an upward trend every year. However, in 2020 the number of tourist arrivals decreased due to the pandemic COVID-19 that hit the country and the world in early 2020. Referring to statistics released by LADA, the highest number of tourist arrivals to Langkawi is in 2019 with a total of 3.9 million tourists (LADA, 2020). Meanwhile, it shows a significant decreased in 2020 with 1.8 million tourists, showing the lowest number of tourist arrivals since 2013. This is outcome of the movement control order that has been enforced by the Malaysian government to curb the spread of the COVID-19.

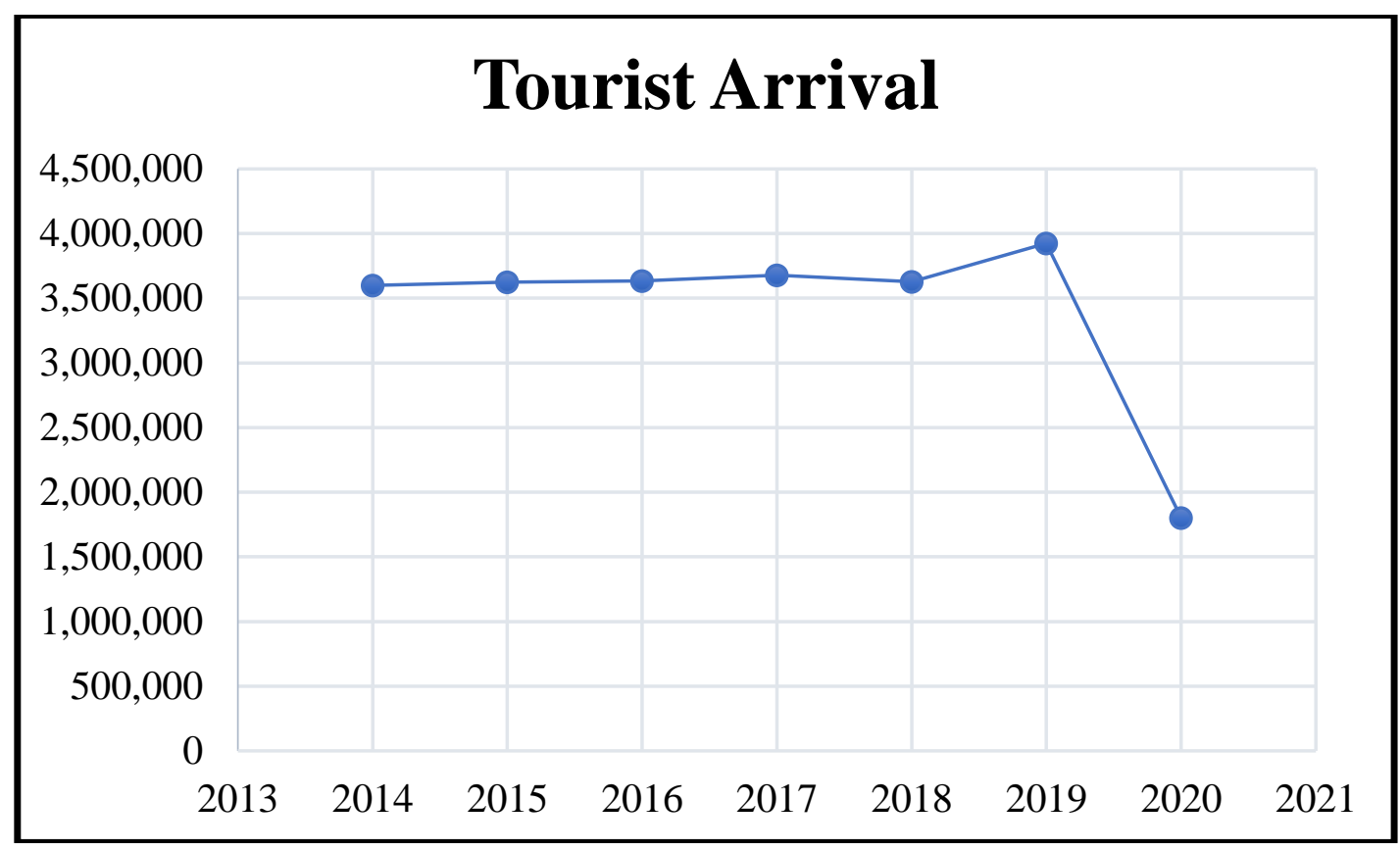

Figure 1.1: Tourist Arrival to Langkawi

Sumber: Statistik Ketibaan Pelawat (LADA, 2020)

\section{c) Tourism Activities in Langkawi}

Tourism in Langkawi started since the day Langkawi is recognized as a Duty Free Island by the Malaysian government in 1987. Langkawi was originally an island with the local community main occupation was fishermen and farmers (Ibrahim \& Ahmad, 2011). The government begun to develop the tourism sector in Langkawi after looking at the potential areas that can be developed as a recreation centre, beaches sanctuary and vacation spot that can be visited by all travellers. 
The development of tourism in Langkawi has led to the creation of employment opportunities and new activities that can attract tourists as well as the local community. This has opened opportunities for local communities to create jobs in the field of tourism. At the same time, there are various activities organized by LADA and the local government such as the Langkawi International Maritime and Aerospace Exhibition (LIMA), Le Tour de Langkawi and The Ironman Langkawi International Trialthon (Ibrahim \& Ahmad, 2011). This is also has become as one of the main attractions for tourists to visit Langkawi.

In addition, the accommodation sector, water sports activities, vehicle rentals, tour guides, boat drivers and various fields of employment under tourism have existed in line with the development of tourism in Langkawi (Din et al., 2020). This has created opportunities for local communities to gain employment and opened opportunities for foreign investors to invest and create recreational centres, for examples, the Langkawi Sky Bridge Cable Car, Underwater World, Kilim Geoforest, Dataran Lang and so on (Langkawi Municipal Council Tourism City, 2021). Each recreation centre that available can provide tourists to feel the atmosphere and beauty of nature as well as to obtain sources of knowledge about the cultural heritage found in Langkawi.

\section{d) Halal Tourism Development in Langkawi}

Langkawi is a district with potential for the development of halal tourism. Halal tourism is a form of tourism that is not foreign to the culture of the community in Langkawi. Langkawi is an area where most of the population are Muslim. This makes Langkawi as one of the potential areas where halal tourism can be developed. According to Kamarudin and Ismail (2012), the development of Halal tourism in Malaysia is gaining recognition.

Looking at the efforts made by the Kedah state government and LADA in developing tourism in Langkawi, it can benefit the Muslim community, especially those in Langkawi. Referring to the Department of Statistics Malaysia (2020), the total Muslim population in Langkawi is 91.7 thousand people which represents $81.1 \%$ of the total population in Langkawi. This shows that the development of halal tourism can be applied in the district of Langkawi. Looking at the activities prearranged by LADA, the local community did not miss the opportunity to work together to succeed in the programmes and activities organized. Among the Muslim friendly events carried out are the LADA Ramadan Tour Program, the Langkawi Ashura Carnival and the Knowledge Talk Program in conjunction with Maal Hijrah (LADA, 2021). From this events, countless benefits and experiences can be gained by the local community and tourists who visit Langkawi, especially those who are Muslims.

The development of halal tourism can further increase the knowledge, creativity, and involvement of the Muslim community in Langkawi in understanding and adhering to all teachings in Islam. According to Mapjabil et al (2015), halal tourism also covers economic, cultural, and historical aspects. In this regard, tourism development in Langkawi can be applied in an integrated manner that includes every form of Islamic-based administratives and operating systems. In fact, the Muslim community is also encouraged to continue working towards upholding halal tourism activities and events. Malaysia is a country that offers halal foods that priotized and focus on the halal status, especially in the offering of nutritional products (Rahman, 2018). Langkawi also has become one of the destinations where Halal 
foods are accessible and easy to find. In fact, foods have become part of an attraction for foreign tourists from Middle Eastern to continue visiting Langkawi.

\section{Conclusion}

The development of halal tourism has given a new dimension to the community in Langkawi. Halal tourism has a wide dimension and covers the entire aspects of life for the Muslim community. Through the development of halal tourism, the community in Langkawi can be benefited from the tourism activities as well as the well-being of the community and tourists. Thus, it can be concluded that the development of the Halal tourism for the Muslim Community in Langkawi has begun and still in a well progressing stage where it contributes to the factor of attraction for the future potential development of halal tourism to be expand and attract more investors, stakeholders, and traveller to visit.

\section{Acknowledgement}

This paper is part of the research done by Nur 'Atiqah Adnan for her Master of Social Science (Islamic Development Management) dissertation entitled Kesan Kemasukan Pelancing Terhadap Gaya Hidup Masyarakat Islam di Langkawi which has been submitted to Universiti Sains Malaysia.

\section{Corresponding Author}

Email: azreenhamiza@usm.my (Azreen Hamiza Abdul Aziz)

\section{References}

Aziz, A. H. B. A. (2018). Muslim Friendly Tourism: Concept, Practices and Challenges in Malaysia. International Journal of Academic Research in Business and Social Sciences, 8(11), 355-363.

Ibrahim, B., Ropi, M. Z. M., Zahidi, N., Abdullah, F., Zulkifli, N. I. Y., \& Chik, W. M. Y. W. (2019). Pelancongan Islam dan Peranannya dalam Mempromosikan Kesejahteraan Hidup di Negeri Terengganu Darul Aman. Proceeding of The International Conference on Islamic Civilization and Technology Management, 214-228.

Camilleri, M. A. (2017). The Tourism Industry: An Overview. Travel Marketing, Tourism Economics and the Airline Product (Chapter 1), 3-27.

Kodirov, U. M. D. (2020). Halal Tourism in Central Asia: Developing Service Systems in Uzbekistan. Journal of Halal Service Research. 1 (2), 35-45.

Dincer, G. C. (2018). Muslim friendly tourism (MFT): A discussion. Journal of Tourismology, 2(1), 65-67.

Rahman, H. A. (2018). Potensi dan Cabaran Dalam Memajukan Pelancongan Islam di Malaysia. Jurnal Sultan Alauddin Sulaiman Shah (Special Issue), 506-518.

Jabatan Perangkaan Malaysia (2019). Laporan Sosioekonomi Negeri Kedah. Putrajaya: Jabatan Perangkaan Malaysia.

Jabatan Perangkaan Malaysia. (2020). Taburan Penduduk Langkawi Mengikut Kaum. Putrajaya: Jabatan Perangkaan Malaysia.

Jabatan Perangkaan Malaysia. (2021). Anggaran Penduduk Malaysia 2021. Putrajaya: Jabatan Perangkaan Malaysia.

Mapjabil, J., Razak, R. R. A., Marzuki, M., \& Zainol, R. M. (2015). Pelancongan Islam: Suatu Tinjauan Konseptual dan Relevannya di Malaysia. GEOGRAFIA Online Malaysia Journal of Society and Space 11, 1, 172-182. 
Jenkins, L. J. (1997). An Introduction to Tourism. Oxford: Butterworh-Heinemann.

Ibrahim, J. A., \& Ahmad, M. Z. (2011). Pelancongan Langkawi 1987 - 2010: Pencapaian dan Cabaran Masa Depan. Persidangan Kebangsaan Ekonomi Malaysia ke VI (PERKEM VI), 1, 602-613.

Lembaga Pembangunan Langkawi. (2021). Komuniti Penglibatan Penduduk Setempat di Langkawi. Retrieved from Laman Web Rasmi Lembaga Pembangunan Langkawi: https://www.lada.gov.my/komuniti/.

Lembaga Pembangunan Langkawi. (2020). Statistik Ketibaan Pelawat. Retrieved from Laman Web Rasmi Lembaga Pembangunan Langkawi: https://www.lada.gov.my/statistik/.

Kamaruddin, L. M. (2018). Konsep Pelancongan Muslim daripada Perspektif Operator

Pelancongan di Malaysia. Tesis Ini Dikemukakan Sebagai Memenuhi Syarat Penganugerahan ljazah Doktor Falsafah (Perancangan Bandar dan Wilayah) Universiti Teknologi Malaysia., 1-61.

Majlis Perbandaran Langkawi Bandaraya Pelancongan. (2021). Tempat Rekreasi . Retrieved from Portal Rasmi Pihak Berkuasa Tempatan Negeri Kedah (PBT) Negeri Kedah Darul Aman: https://pbt.kedah.gov.my/index.php/majlis-perbandaranlangkawi-bandaraya-pelancongan/.

Mokhtar, M., Ta, G. C., Yahya, S., \& Shamshiry, E. (2010). Pelaksanaan Pendekatan Bersepadu untuk Melindungi Alam Sekitar dan Kesejahteraan Komuniti di Langkawi Geopark. Akademika 80, 105-112.

Said, N. A., \& Khairuldin. (2017). Freedom of Speech in Islam and its Connection with Street Demonstrations. International Journal of Academic Research in Business and Social Sciences, 7(4), 122-129.

Khairuldin, Embong, A. H., Anas, W. N. I. W. N., Ismail, D., Ibrahim, I., \& Fauzi, N. (2017). Freedom of Speech: A Comparative Study between Islam and Malaysian Laws. International Journal of Academic Research in Business and Social Sciences, 7(2), 2222-6990.

Ibrahim, I., \& Khairuldin. (2017). Fatwa as a Medium Da'wah: Studies on the Role of Mufti as a Preacher. International Journal of Academic Research in Business and Social Sciences, 7(4), 10-18.

Battour, M., \& Ismail, M. N. (2015). Halal tourism: Concepts, practises, challenges and future. Tourism Management Perspectives, 1-5.

Din, N. F. M., Ahmad, H., Jusoh, H., \& Aiyub, K. (2020). Pola Kunjungan Pelancongan Keluarga Berasaskan Aktiviti Sebelum, Semasa dan Selepas ke Pantai Pelancongan Pulau: Pantai Chenang Langkawi. Malaysian Journal of Social Sciences and Humanities (MJSSH), 5(1), 69-81.

Rasit, R. M., Hamjah, S. H., Tibek, S. R., Ashaari, M. F., Samsudin, M. A., Aini, Z. \& Mokhtar, A. I. (2014). Industri Pelancongan Islam dan Pembangunan Etnik di Malaysia. Seminar Antarabangsa Dakwah \& Etnik 2014; Dakwah \& Etnik: Perspektif Multi-disiplin, 1-11. Ismail, S. (2015). Social Impact of Tourism Development on Local Community in Mukim Kedawang, Langkawi Island. Thesis Calon Ijazah Sarjana Sains, Universiti Sains Malaysia. 